\title{
Political Scientists Receive Guggenheim Fellows
}

U nited States Senator Simon Guggenheim and his wife established the John Simon Guggenheim Memorial Foundation in 1925 as a memorial to a son who died April 26, 1922. The Foundation offers Fellowships to further the development of scholars and artists by assisting them to engage in research in any field of knowledge and creation in any of the arts, under the freest possible conditions and irrespective of race, color, or creed. The Foundation receives between 3,500 and 4,000 applications each year. Although no one who applies is guaranteed success in the competition, there is no prescreening: all applications are reviewed. Approximately 200 Fellowships are awarded each year.

Often characterized as "midcareer" awards, Guggenheim Fellowships are intended for men and women who have already demonstrated exceptional capacity for productive scholarship or exceptional creative ability in the arts. The following APSA members received fellowships this year.

\section{MARK R. BEISSINGER}

Mark R. Beissinger is the Henry W. Putnam Professor of Politics at Princeton Uni-

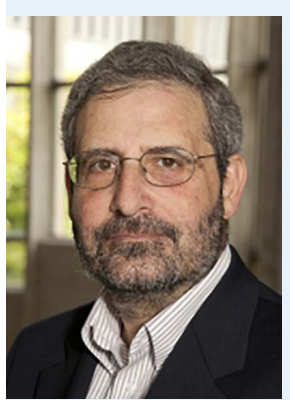
versity, where he has been director of the Princeton Institute for International and Regional Studies. He previously served on the faculties of Harvard University and the University of Wisconsin-Madison and received his BA from Duke University and PhD from Harvard University.

Beissinger's main areas of interest are social movements, revolutions, nationalism, state-building, and imperialism, with particular geographic focus on Russia and the post-Soviet states. In addition to numerous articles and book chapters, Beissinger is author or editor of five books. His book Nationalist Mobilization and the Collapse of the Soviet State (2002) received multiple awards, including the Woodrow Wilson Foundation Award for the best book published in the United States in the field of government, politics, or international affairs as well as the Mattei Dogan Award for the best book published in the field of comparative research.

Beissinger has held residential fellowships at the Institute for Advanced Study at Princeton, the Wissenschaftskolleg zu Berlin, the Woodrow Wilson International Center for Scholars, and the Davis Center for Russian and Eurasian Studies at Harvard University. His work has also been supported by the National Science Foundation, the National Endowment for the Humanities, Fulbright-Hays, IREX, and the Ford, Rockefeller, and Olin Foundations, and he has served as president of the American Association for the Advancement of Slavic Studies.

Beissinger's Guggenheim project concerns how revolution as a mode of regimechange has evolved globally over the past century-and in particular, the impact of urbanization on the incidence, forms, processes, and consequences of mass revolt.

\section{WENDY BROWN}

Wendy Brown is Class of 1936 First Chair in the Department of Political Science at the University of California, Berkeley where she is also affiliated with the interdisciplinary graduate program in critical theory. Brown received her BA in politics and economics from the University of California, Santa Cruz, and her PhD in political philosophy from Princeton University. She has held recent visiting appointments at the European Graduate School, the

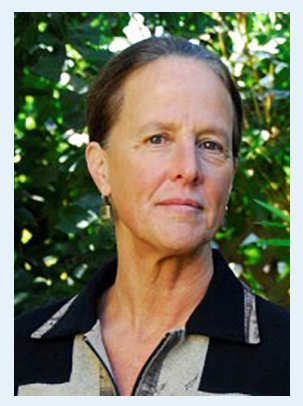

London School of Economics, Cornell University, Columbia University and the Critical Theory Summer School at the University of London, Birkbeck. A dedicated teacher of graduate and undergraduate students, she received a Distinguished Teaching Award at University of California, Berkeley in 2016.

In her research, Brown draws from the history of Western political thought, political economy, and recent Continental thought to illuminate contemporary predicaments of power, freedom, and democracy. Her most recent book is Undoing the Demos: Neoliberalism's Stealth Revolution (2015), which theorizes neoliberalism's corrosion of democratic values, practices, institutions and imaginaries, and generation of anti-democratic political formations. In addition to her singleauthored books, she has collaborated on several volumes, including The Power of Tolerance: A Debate Between Wendy Brown and Rainer Forst (2014). She also writes and lectures extensively on current challenges to public higher education.

The Guggenheim Fellowship will support the research and writing of a book-length study of Marx's critique of religion. Against the received view that Marx abandoned his early intellectual interest in religion with his turn to political economy, this book will show that Marx's understanding of the generation of religious consciousness in class societies is crucial to his later work, even contributing to the epistemological underpinnings of Das Kapital. The book will also draw Marx's account into reflections on several contemporary debates concerning religion, secularism, and capitalism. 